\title{
A negatív érzelmek és a szív- és érrendszeri betegségek összefüggései
}

\author{
Balog Piroska
}

Semmelweis Egyetem, Általános Orvostudományi Kar, Magatartástudományi Intézet, Budapest

\begin{abstract}
A cardiovascularis egészség szempontjából a negatív érzelmek közül a depresszió, a szorongás, a vitális kimerültség és az ellenségesség szerepét vizsgálták a leggyakrabban. A depresszió tünetei közül elsősorban a szomatikus tünetek, a szorongást illetően pedig elsősorban a generalizált szorongás és a pánik hozható összefüggésbe a szív- és érrendszeri betegségekkel. Myocardialis infarctuson átesett betegek interjúit elemezve azt találták, hogy vitális kimerültség előzi meg az infarktust, vagyis a fáradtság, az energiahiány, az ingerlékenység és egy általános demoralizáció együttese. A vitális kimerültség bizonyítottan hozzájárul a szív- és érrendszeri betegségek kialakulásához, és mindkét nemnél a szívbetegségek egyik legerősebb rizikófaktora. Az ellenségességet illetően a kutatások azt mutatták, hogy a harag elfojtása, valamint a harag destruktív kifejezése (mások hibáztatása) mutatott szoros összefüggést a szív- és érrendszeri betegségekkel. Az is igazolást nyert, hogy az ok-okozati összefüggés a negatív érzelmek és a szív- és érrendszeri betegségek között kétirányú, vagyis a szív- és érrendszeri betegségek megléte is hozzájárul a negatív érzelmek fokozódásához, és mindkét betegségcsoportban az alacsony szívritmus-variabilitás játssza a főszerepet. A tanulmány az Európai Irányelvek (2016) által a negatív érzelmek vizsgálatára javasolt kérdéssort is bemutatja.
\end{abstract}

Orv Hetil. 2018; 159(48): 2005-2010.

Kulcsszavak: negatív érzelmek, szív- és érrendszeri betegségek, szakirodalmi összefoglaló

\section{Negative emotions associated with cardiovascular diseases}

With regard to cardiovascular health, the role of negative emotions, particularly that of depression, anxiety, vital exhaustion and hostility has been studied the most widely. Mainly the somatic symptoms of depression and, out of anxiety disorders, generalised anxiety and panic disorder have been linked to cardiovascular diseases. Based on an analysis of interviews of patients having suffered myocardial infarction, it was found that vital exhaustion (a combination of loss of energy, increased irritability, and general demoralization) is a precursor of infarction. Vital exhaustion has proven to contribute to the development of coronary heart diseases, being one of the most important risk factors in both sexes. With regard to hostility, studies show that anger suppression and destructive anger expression (blaming others) are closely linked to a higher incidence of coronary heart diseases. Evidence shows that the relationship between negative emotions and cardiovascular diseases is one of a two-way causality, that is, the presence of a cardiovascular disease may also enhance negative emotions, low heart rate variability playing a crucial role in both diseases. This study also presents interview questions suggested by the European Guidelines (2016) to estimate negative emotions related to coronary heart diseases.

Keywords: negative emotions, cardiovascular diseases, review

Balog P. [Negative emotions associated with cardiovascular diseases]. Orv Hetil. 2018; 159(48): 2005-2010.

Beérkezett: 2018. június 12.; elfogadva: 2018. július 7.)

\section{Rövidítések}

$\mathrm{CRP}=$ C-reaktív protein; EKG = elektrokardiográfia $; \mathrm{IL}=$ interleukin; SCORE = (Systematic Coronary Risk Evaluation $)$ Cardiovascularis Rizikóbecslő Rendszer; $\mathrm{UH}$ = ultrahang

\section{Depresszió}

A szív- és érrendszeri betegségek patogenezisében (kialakulásában és progressziójában) szerepet játszó negatív érzelmek közül a leginkább kutatott a depresszió jelen- 
tősége. Bebizonyították, hogy a depressziós tünetek egyrészt egészséges személyeknél előre jelzik a szív- és érrendszeri betegségeket [1], másrészt a már szívbetegek körében növelik a morbiditást és a mortalitást, a meglévő szívbetegség súlyosságától függetlenül [2]. Ráadásul több áttekintő tanulmány szerint nemcsak a súlyos, klinikai depresszió, de már az enyhe, szubklinikai depressziós tünetek is növelik a cardiovascularis morbiditást és mortalitást [3], és ez az összefüggés kimutatható nőknél-férfiaknál egyaránt, kulturális különbségektől függetlenül [4]. Az ezredfordulót követően a kutatókban felmerült az a kérdés, hogy vajon inkább a depresszió kognitív tünetei (lehangoltság, pesszimizmus, büntudat, alacsony önértékelés, önhibáztatás) vagy inkább a depresszió szomatikus tünetei (fáradtság, alvászavar, étvágytalanság, mozgáshiány, motivációhiány) felelősek ezért az összefüggésért $[5,6]$. A napjainkig megjelent tudományos eredmények szerint a depresszió szomatikus tünetei fontosabb szerepet játszanak a szív- és érrendszeri betegségek és halálozás előrejelzésében, mint a kognitív tünetek $[7,8]$. Vagyis a szívbetegek depressziója nem „ugyanaz” a depresszió, mint a pszichiátriai betegek depressziója, amelynél viszont a kognitív tünetek hangsúlyosabbak. A depresszió két faktorának eltérő hatásmechanizmusa talán magyarázatul szolgál a depressziós tünetek enyhítését és a prognózis javítását célzó sikertelen (gyógyszeres vagy kognitív terápiás) intervenciókra is. Az intervenciók hatására ugyanis valamelyest csökkentek a depressziós tünetek, de a legjobban várt eredmény - a javulás a kardiológiai prognózisban - nem következett be $[9,10]$. Tehát a depresszió kognitív tüneteinek javítására tervezett terápiás programok és a gyógyszerek nem váltották be a hozzájuk füzött reményeket a szívbetegek körében.

$\mathrm{Az}$ is igazolást nyert, hogy az ok-okozati összefüggés a depresszió és a szív- és érrendszeri betegségek között kétirányú, vagyis a szív- és érrendszeri betegségek megléte is hozzájárul a depressziós tünetek fokozódásához, és mindkét betegség patogenezisében az alacsony szívritmus-variabilitás játssza a főszerepet $[11,12]$. Mindemellett a kutatók egy része felvetette azt a hipotézist is, hogy mind a depressziós tünetek, mind a szív-és érrendszeri betegségek tulajdonképpen egy közös rizikófaktornak, a szubklinikai atheroscleroticus folyamatoknak a következményei. A szakirodalomban ismertté vált a „vascularis depresszió" fogalma, vagyis hogy vascularis zavarok okoznák a depressziót, új kihívások elé állítva a kutatókat, klinikusokat egyaránt $[13,14]$.

\section{Szorongás}

A depresszióhoz hasonlóan a szorongás is gyakoribb a szív- és érrendszeri betegek körében, mint az egészséges kontrollszemélyeknél. A szorongás és a szív- és érrendszeri betegségek összefüggéseit követéses vizsgálatok igazolták [15, 16]. A szorongás és az aggódás csökkent szívritmus-variabilitással [17], a coronariabetegségek fo- kozottabb előfordulásával járnak együtt [18], és rontják a meglévő szívbetegség prognózisát [19].

Akárcsak a depressziós tünetek esetében, itt is felmerült a kétirányú kauzalitás lehetősége: a szívbetegség fokozott szorongással jár együtt, tehát a szorongás nemcsak oka, hanem következménye is a kardiológiai betegségeknek, és az infarktust követő kezeletlen szorongás tovább rontja a szívbetegek esélyeit [20].

A depresszió és a szorongásos zavarok gyakran együtt járnak: a depressziós betegek szoronganak is, és a szorongással küzdő betegek körében depressziós tünetek is megjelennek, így a szív- és érrendszeri betegek esetében gyakran komorbid hatásokról beszélhetünk [21]. Amikor a hosszú távú, követéses vizsgálatokban a depressziónak és a szorongásnak a szív- és érrendszeri betegségekre gyakorolt hatásait egy modellben elemezték, akkor a szorongás hatása erôsebbnek bizonyult. Ezt az összefüggést találták egy 37 éves követéses vizsgálatban, amelyben egészséges fiatal felnőttek korai szorongása szorosan összefüggött a követés alatt bekövetkező szíveseményekkel, a korai depresszió viszont nem [22], és ezt találták szívbetegek körében is: a mútét előtt mért vonásszorongás szorosan összefüggött a mortalitással, a depresszió viszont nem [23].

Amikor a különböző szorongásos zavaroknak (pánik, fóbiák, aggódás, genaralizált szorongás) a szív- és érrendszerre gyakorolt hatásait külön elemezték, akkor a legerősebb összefüggést a szív- és érrendszeri betegségekkel az állandó aggódás (genaralizált szorongás) mutatta [24], ugyanakkor más tanulmányok a pánik és a szívbetegségek között találtak erős független összefüggést [25]. A pánik növeli a myocardialis infarctus [26] és a stroke valószínúségét is [27]. Egy kutatócsoport arra hívta fel a figyelmet, hogy a pánik szomatikus tünetei szorosabb összefüggést mutatnak a szív- és érrendszeri betegségekkel, mint a kognitív tünetek, és ebben az öszszefüggésben a közvetítő szerepet feltehetően a mozgásszegény életmód játssza [28].

Hogyan különböztethető meg a pánikroham a szívrohamtól? A pánikbetegek a sürgősségi osztályokon gyakrabban jelennek meg, és gyakrabban hívják az SOS-számokat, mint a nem pánikbetegek [29], a leggyakrabban mellkasi fájdalommal, a szívroham gyanújával [30], de ennek 60-90\%-a később nem bizonyul cardialis eredetünek [31]. Egy laikusnak nehéz különbséget tennie, mert nagy átfedés van a tünetek között: a mellkasi fájdalom, a légzészavar és az erôs szorongás mindkettőre jellemző lehet [32].

\section{Szívroham}

A fájdalom típusa: a szegycsont mögött jelentkező szorító, nyomó, markoló jellegű mellkasi fájdalom, mely a bal vállba, karba és a bal kéz kisujja felé sugárzik, változatlan intenzitással órákon át tart.

Mechanizmus: a szívet tápláló koszorúerek elzáródnak, a szívizomzat nem jut elég vérhez, az oxigénhiány az 
izomrostok elhalásához vezet, romlik a szív pumpafunkciója, esik a vérnyomás.

A fájdalom jelentkezése: gyakran fizikai vagy pszichés terhelésre; korai figyelmeztető jel: olyan vissza-visszatérő mellkasi fájdalom, amely mozgásra erősödik és pihenésre szünik.

Rizikótényezốk: életkor, nem, életmód - dohányzás, mozgáshiány, alkohol, krónikus stressz.

Anamnézis: korábbi szívesemény.

Családi anamnézis: elsőfokú rokoni ágon szív- és érrendszeri betegség.

\section{Pánikroham}

A fájdalom tipusa: mellkasi fájdalom, de azon belül nehezen lokalizálható, több ponton fáj - hirtelen alakul ki, rövid időn belül eléri a maximumát, majd lassan lecseng, csökken az intenzitása.

Mechanizmus: az agy indokolatlan vészjelzése indítja el, ennek hatására a mellékvesékből adrenalin szabadul fel és kerül a keringésbe, kialakul az 'üss vagy fuss' reakció: heves szívdobogás, mellkasi fájdalom, gyors, felületes légzés, fulladásérzés, izzadás, remegés, szédülés, esetleg fényérzékenység, a végtagok zsibbadása.

A fájdalom jelentkezése: általában nyugalmi helyzetben, gyakran jelentkezik zárt helyeken, boltban, közlekedési eszközökön.

Rizikótényezők: megváltozott élethelyzet, akut vagy krónikus stressz, krízis.

Anamnézis: szorongás vagy más pszichiátriai kórelőzmény.

Családi anamnézis: szorongás, depresszió, addikció a családban.

A differenciáldiagnózishoz elvégzendō vizsgálatok: fizikális vizsgálat, vérnyomásmérés, EKG, UH, terheléses EKG, angiográfia, koronarográfia; laborvizsgálatok: vércukor, koleszterin, vesefunkciók, májfunkciók, pajzsmirigyfunkciók.

Minden esetben meg kell vizsgálni, hogy szíveredetü-e a beteg panasza, szükség van-e azonnali beavatkozásra. Amennyiben a differenciáldiagnosztikai vizsgálatok alapján teljességgel kizárható a mellkasi fájdalom cardialis eredetete, felmérjük a szorongás intenzitását. Itt is érdemes a komorbiditásra gondolnunk: a korábban átélt szívinfarktus fokozott önmegfigyeléssel könnyen átcsúszhat pánikzavarba, az átélt pánikzavar pedig provokálhat szíveseményt, vagyis a betegnek egyszerre lehet pánikbetegsége és szív- és érrendszeri betegsége, ilyenkor mindkét betegség kezelendő. Egy áttekintő tanulmány hangsúlyozza, hogy a szívbetegek 10-50\%-a pánikzavarral is küzd [33]. Fontos, hogy biopszichoszociális szemléletben gondolkodjunk: vagyis egyaránt lényeges az infarktuson átesett beteg szorongását mérni és adott esetben kezelni (csökkenteni), akárcsak a pánikbetegség megfelelő kezelése, a cardialis morbiditás prevenciója szempontjából is. Tehát ha egy betegnél pánikbetegséget diagnosztizáltak, a pánikbetegség kezelése mellett (mozgás- és kognitív viselkedésterápiás technikák alkalmazásával) a klinikusnak éberen kell követnie a beteg szív- és érrendszeri egészségi állapotát is [34].

\section{Vitális kimerültség}

Appels és mtsai [35] infarktuson átesett betegeket interjúvoltak meg, hogy minél pontosabb képet kapjanak arról a pszichés állapotról, azokról a tünetekről, amelyek megelőzték az infarctust. Így jutottak el a vitális kimerültség megfogalmazásához, mely röviden összefoglalva nem más, mint egy kombinációja a fáradtságnak (energiahiánynak), az ingerlékenységnek és egy általános demoralizációnak. A vitális kimerültség előre jelzi az akut myocardialis infarctust [36], rontja a prognózist [37], növeli a stroke valószínúségét [38], és zárkózottsággal (az érzelmek ki nem fejezésével) társulva növeli a hirtelen szívhalál veszélyét [39].

A napjainkban megjelent áttekintő tanulmányok is hangsúlyozzák, hogy a vitális kimerültség bizonyítottan hozzájárul a szív- és érrendszeri betegségek kialakulásához, rontja a meglévő betegségek prognózisát [40], és mindkét nemnél a szívbetegségek egyik legerősebb rizikófaktora [41]. Ami a patofiziológiai mechanizmusát illeti, a vitális kimerültség felborítja a hemosztatikus egyensúlyt, károsítva a fibrinolysist, hozzájárul a thrombusképződéshez $[42,43]$, a gyulladásos markerek (CRP, IL6) magas koncentrációjával [44] és nagyobb szérumtriglicerid-szinttel [45] jár együtt.

A vitális kimerültség erőteljesen korrelál a depressziós tünetegyüttessel; a kutatók egy része amellett érvel, hogy tulajdonképpen nem is különbözik e két tünetegyüttes. A depressziót és a vitális kimerültséget egy modellben elemző tanulmányok szerint valóban van egy átfedés: a depresszió szomatikus komponense és a kimerültség magas korrelációt mutat $[46,47]$, és mindkettő szorosan összefüggött a rosszabb kardiológiai prognózissal, a depresszió kognitív komponense viszont nem. Ezt az összefüggést, miszerint a depresszió és a vitális kimerültség két különböző konstrukció (és a különbség elsősorban a kognitív tünetekból adódik), valamint hogy a vitális kimerültség a szív- és érrendszeri betegségek erőteljesebb rizikófaktora, mint a depresszió, magyar reprezentatív mintán is igazoltuk [48]. A kutatók hangsúlyozzák, hogy a depresszió mellett mára a vitális kimerültségre vonatkozó kérdések is az anamnézis rutinkérdései közé kellene, hogy tartozzanak [49], és javasolják bevenni a coronariabetegségek korai felismerésére tervezett SCORE kérdései közé [50].

\section{Ellenségesség}

A negatív érzelmek közül még az ellenségesség, a harag szerepét fontos megemlíteni.

A szakirodalmat böngészve kezdetben ellentmondásos eredményeket találunk. Eng és mtsai [51] azt találták, hogy a harag moderált kifejezése az infarktussal és a 
stroke-kal szemben protektív tényező, később pedig kimutatták, hogy a cinikus, ellenséges hozzáállás növeli a szívinfarktus veszélyét $[52,53]$. Az állandó feszültség, harag, a bizalmatlan, ellenálló (antagonisztikus) viselkedés, ha kismértékben is, de hozzájárul a szív- és érrendszeri betegségek kiváltásához, és rontja a prognózist [54]. Ami a patofiziológiai mechanizmust illeti, a harag, az ellenséges magatartás fokozott szimpatikus idegrendszeri aktivitással, alacsony szívritmus-variabilitással, a plakkaggregáció és a gyulladásos folyamatok emelkedett szintjével hozható összefüggésbe [55]. Mivel a harag természetes, általános, mindannyiunk életében előforduló negatív érzelem, a kutatók feltették a kérdést, hogy inkább a harag kifejezése, vagy a harag elfojtása (ki nem fejezése), illetve a harag kifejezésének mely formája az egészségkárosító. A harag kifejezésének különböző formáit elemző vizsgálatok rámutattak arra, hogy a harag elfojtása rosszabb alvásminőséggel jár együtt [56], valamint összefüggést mutat korai atheroscleroticus folyamatokkal [57], illetve a gyakran előforduló destruktív harag (mások hibáztatása) jósolja meg a szívesemények gyakoribb előfordulását [58]. A dühroham kontrollálása is szoros, fordított irányú összefüggést mutatott a szívés érrendszeri betegségekkel, vagyis azok körében, akik jobban tudják kontrollálni a haragjukat, alacsonyabb a szív- és érrendszeri rizikó [52]. Néhány tanulmány pedig a nemi különbségeket hangsúlyozza: az ellenségesség erősebb rizikófaktor a rosszabb kardiológiai prognózisra vagy a halálozásra férfiaknál, mint nőknél [59], illetve a harag konstruktív kifejezése csak férfiaknál volt protektív [58]. Tekintettel arra, hogy a tartós ellenségesség, harag később növeli a depressziós tünetek számát [60], ami bizonyított cardialis rizikótényező - ugyanakkor ismert, hogy a harag kontrollálása készségfejlesztő tréningekkel tanítható -, érdemes lenne a harag kifejezésének módjaira is rákérdezni az anamnézis során.

A negatív érzelmek vizsgálati eszközei validált, standardizált kérdőívek, illetve az Európai Irányelvek (European Guidelines, 2016) által javasolt kérdéssor [61].

A szív- és érrendszeri betegségek megelőzésére fókuszálva az Európai Irányelvek (European Guidelines, 2016) a negatív érzelmek korai felismerésére a következő kérdéseket javasolják bevezetni az anamnézis rutinkérdései közé:

Depresszió

Lehangoltnak, depressziósnak, reménytelennek érzi magát? Úgy érzi, hogy elveszítette az érdeklődését és életkedvét?

Szorongás

Előfordul, hogy hirtelen félelem vagy pánik lesz úrrá Önön? Gyakran előfordul, hogy képtelen megállítani vagy kontrollálni az aggódását?
Ellenségesség

Gyakran előfordul az, hogy apróságok miatt is nagyon dühös lesz?

Gyakran érzi azt, hogy mások viselkedése bosszúságot okoz önnek?

Más mentális betegség Van Önnek bármilyen más mentális betegsége?

Anyagi támogatás: A tanulmány elkészítése anyagi támogásban nem részesült.

A cikk végleges változatát a szerző elolvasta és jóváhagyta.

Érdekeltségek: A szerzőnek nincsenek érdekeltségei.

\section{Irodalom}

[1] Janszky I, Ahlbom A, Hallqvist J, et al. Hospitalization for depression is associated with an increased risk for myocardial infarction not explained by lifestyle, lipids, coagulation, and inflammation: the SHEEP Study. Biol Psychiatry 2007; 62: 25-32.

[2] Meijer A, Conradi HJ, Bos EH, et al. Adjusted prognostic association of depression following myocardial infarction with mortality and cardiovascular events: individual patient data metaanalysis. Br J Psychiatry 2013; 203: 90-102.

[3] Sheps DS, Rozanski A. From feeling blue to clinical depression: exploring the pathogenicity of depressive symptoms and their management in cardiac practice. Psychosom Med. 2005; 67(Suppl 1): S2-S5.

[4] Loerbroks A, Bosch JA, Mommersteeg PM, et al. The association of depression and angina pectoris across 47 countries: findings from the 2002 World Health Survey. Eur J Epidemiol. 2014; 29: 507-515.

[5] de Jonge P, Mangano D, Whooley MA. Differential association of cognitive and somatic depressive symptoms with heart rate variability in patients with stable coronary heart disease: findings from the Heart and Soul Study. Psychosom Med. 2007; 69: 735-739.

[6] de Jonge P, Ormel J, van den Brink RH, et al. Symptom dimensions of depression following myocardial infarction and their relationship with somatic health status and cardiovascular prognosis. Am J Psychiatry 2006; 163: 138-144.

[7] Roest AM, Thombs BD, Grace SL, et al. Somatic/affective symptoms, but not cognitive/affective symptoms, of depression after acute coronary syndrome are associated with 12 -month allcause mortality. J Affect Disord. 2011; 131: 158-163.

[8] de Miranda Azevedo R, Roest AM, Hoen PW, et al. Cognitive/ affective and somatic/affective symptoms of depression in patients with heart disease and their association with cardiovascular prognosis: a meta-analysis. Psychol Med. 2014; 44: 2689-2703.

[9] Berkman LF, Blumenthal J, Burg M, et al. Effects of treating depression and low perceived social support on clinical events after myocardial infarction: the Enhancing Recovery in Coronary Heart Disease Patients (ENRICHD) randomized trial. JAMA 2003; 289: 3106-3116.

[10] van Melle JP, de Jonge P, Honig A, et al. Effects of antidepressant treatment following myocardial infarction. Br J Psychiatry 2007; 190: 460-466.

[11] Stapelberg NJ, Hamilton-Craig I, Neumann DL, et al. Mind and heart: heart rate variability in major depressive disorder and cor- 
onary heart disease - a review and recommendations. Aust N Z J Psychiatry 2012; 46: 946-957.

[12] Kidwell M, Ellenbroek BA. Heart and soul: heart rate variability and major depression. Behav Pharmacol. 2018; $29(2$ and 3 Special Issue): 152-164.

[13] Thomas AJ, Kalaria RN, O'Brien JT. Depression and vascular disease: what is the relationship? J Affect Disord. 2004; 79: 8195.

[14] Taylor WD, Aizenstein HJ, Alexopoulos GS. The vascular depression hypothesis: mechanisms linking vascular disease with depression. Mol Psychiatry 2013; 18: 963-974.

[15] Roest AM, Martens EJ, de Jonge P, et al. Anxiety and risk of in cident coronary heart disease: a meta-analysis. J Am Coll Cardiol. 2010 ; 56: 38-46.

[16] Thurston RC, Rewak M, Kubzansky LD. An anxious heart: anxiety and the onset of cardiovascular diseases. Prog Cardiovasc Dis. 2013; 55: 524-537.

[17] Chalmers JA, Quintana DS, Abbott MJ, et el. Anxiety disorders are associated with reduced heart rate variability: a meta-analysis Front Psychiatry 2014; 5: 80

[18] Tully PJ, Cosh SM, Baune BT. A review of the affects of worry and generalized anxiety disorder upon cardiovascular health and coronary heart disease. Psychol Health Med. 2013; 18: 627644.

[19] AbuRuz ME. Persistent anxiety and in-hospital complications after acute coronary syndrome. Int J Health Sci (Qassim). 2018; 12: 50-56.

[20] Norlund F, Lissåker C, Wallert J, et al. Factors associated with emotional distress in patients with myocardial infarction: results from the SWEDEHEART registry. Eur J Prev Cardiol. 2018; 25: 910-920

[21] Tully PJ, Baune BT. Comorbid anxiety disorders alter the association between cardiovascular diseases and depression: the German National Health Interview and Examination Survey. Soc Psychiatry Psychiatr Epidemiol. 2014; 49: 683-691.

[22] Janszky I, Ahnve S, Lundberg I, et al. Early-onset depression, anxiety, and risk of subsequent coronary heart disease: 37-year follow-up of 49,321 young Swedish men. J Am Coll Cardiol. 2010; 56: 31-37.

[23] Székely A, Balog P, Benkö E, et al. Anxiety predicts mortality and morbidity after coronary artery and valve surgery - a 4 -year follow-up study. Psychosom Med. 2007; 69: 625-631.

[24] Batelaan NM, ten Have M, van Balkom AJ, et al. Anxiety disorders and onset of cardiovascular disease: the differential impact of panic, phobias and worry. J Anxiety Disord. 2014; 28: 252-258.

[25] Machado S, Sancassiani F, Paes F, et al. Panic disorder and cardiovascular diseases: an overview. Int Rev Psychiatry 2017; 29 436-444.

[26] Chen YH, Tsai SY, Lee HC, et al. Increased risk of acute myocardial infarction for patients with panic disorder: a nationwide population-based study. Psychosom Med. 2009; 71: 798-804.

[27] Chen $\mathrm{YH}, \mathrm{Hu} \mathrm{CJ}$, Lee HC, et al. An increased risk of stroke among panic disorder patients: a 3-year follow-up study. Can J Psychiatry 2010; $55: 43-49$.

[28] Belem da Silva CT, Schuch F, Costa M, et al. Somatic, but not cognitive, symptoms of anxiety predict lower levels of physical activity in panic disorder patients. J Affect Disord. 2014; 164: 63-68.

[29] Zane RD, McAfee AT, Sherburne S, et al. Panic disorder and emergency services utilization. Acad Emerg Med. 2003; 10: 1065-1069.

[30] Foldes-Busque G, Denis I, Poitras J, et al. A closer look at the relationships between panic attacks, emergency department visits and non-cardiac chest pain. J Health Psychol. 2017 Jan 5. https:// doi.org/10.1177/1359105316683785 [Epub ahead of print]

[31] Kachintorn U. How do we define non-cardiac chest pain? J Gastroenterol Hepatol. 2005; 20(Suppl): S2-S5.
[32] Katerndahl DA. Chest pain and its importance in patients with panic disorder: an updated literature review. Prim Care Companion J Clin Psychiatry 2008; 10: 376-383.

[33] Fleet R, Lavoie K, Beitman BD. Is panic disorder associated with coronary artery disease? A critical review of the literature. J Psychosom Res. 2000; 48: 347-356.

[34] Sardinha A, Araújo CG, Soares-Filho GL, et al. Anxiety, panic disorder and coronary artery disease: issues concerning physical exercise and cognitive behavioral therapy. Expert Rev Cardiovasc Ther. 2011; 9: 165-175.

[35] Appels A, Höppener P, Mulder P. A questionnaire to assess premonitory symptoms of myocardial infarction. Int J Cardiol. 1987; 17: 15-24.

[36] Schuitemaker GE, Dinant GJ, van der Pol GA, et al. Assessment of vital exhaustion and identification of subjects at increased risk of myocardial infarction in general practice. Psychosomatics 2004; 45: 414-418.

[37] Smith OR, Kupper N, Denollet J, et al. Vital exhaustion and cardiovascular prognosis in myocardial infarction and heart failure: predictive power of different trajectories. Psychol Med. 2011; 41: 731-738.

[38] Kornerup H, Marott JL, Schnohr P, et al. Vital exhaustion increases the risk of ischemic stroke in women but not in men: results from the Copenhagen City Heart Study. J Psychosom Res. 2010; 68: 131-137.

[39] Appels A, Golombeck B, Gorgels A, et al. Behavioral risk factors of sudden cardiac arrest. J Psychosom Res. 2000; 48: 463-469.

[40] Frestad D, Prescott E. Vital exhaustion and coronary heart disease risk: a systematic review and meta-analysis. Psychosom Med. 2017; 79: 260-272.

[41] Schnohr P, Marott JL, Kristensen TS, et al. Ranking of psychosocial and traditional risk factors by importance for coronary heart disease: the Copenhagen City Heart Study. Eur Heart J. 2015; 36: 1385-1393.

[42] van Diest R, Hamulyák K, Kop WJ, et al. Diurnal variations in coagulation and fibrinolysis in vital exhaustion. Psychosom Med. 2002; 64: 787-792.

[43] von Känel R, Frey K, Fischer J. Independent relation of vital exhaustion and inflammation to fibrinolysis in apparently healthy subjects. Scand Cardiovasc J. 2004; 38: 28-32.

[44] Kwaijtaal M, van Diest R, Bär FW, et al. Inflammatory markers predict late cardiac events in patients who are exhausted after percutaneous coronary intervention. Atherosclerosis 2005; 182: 341-348

[45] Igna CV, Julkunen J, Vanhanen H. Vital exhaustion, depressive symptoms and serum triglyceride levels in high-risk middle-aged men. Psychiatry Res. 2011; 187: 363-369.

[46] Kop WJ. Somatic depressive symptoms, vital exhaustion, and fa tigue: divergent validity of overlapping constructs. Psychosom Med. 2012; 74: 442-445.

[47] Vroege EM, Zuidersma M, de Jonge P. Vital exhaustion and somatic depression: the same underlying construct in patients with myocardial infarction? Psychosom Med. 2012; 74: 446-451.

[48] Balog P, Falger PR, Szabó G, et al. Are vital exhaustion and depression independent risk factors for cardiovascular disease morbidity? Health Psychol. 2017; 36: 740-748.

[49] Purebl Gy, Birkás E, Csoboth C, et al. The relationship of biological and psychological risk factors of cardiovascular disorders in a large-scale national representative community survey. Behav Med. 2006; 31: 133-139.

[50] Graversen P, Abildstrøm SZ, Jespersen L, et al. Cardiovascular risk prediction: can Systematic Coronary Risk Evaluation (SCORE) be improved by adding simple risk markers? Results from the Copenhagen City Heart Study. Eur J Prev Cardiol. 2016; 23: 1546-1556.

[51] Eng PM, Fitzmaurice G, Kubzansky LD, et al. Anger expression and risk of stroke and coronary heart disease among male health professionals. Psychosom Med. 2003; 65: 100-110. 
[52] Haukkala A, Konttinen H, Laatikainen T, et al. Hostility, anger control, and anger expression as predictors of cardiovascular disease. Psychosom Med. 2010; 72: 556-562.

[53] Izawa S, Eto Y, Yamada KC, et al. Cynical hostility, anger expression style, and acute myocardial infarction in middle-aged Japanese men. Behav Med. 2011; 37: 81-86.

[54] Chida Y, Steptoe A. The association of anger and hostility with future coronary heart disease: a meta-analytic review of prospective evidence. J Am Coll Cardiol. 2009; 53: 936-946.

[55] Suls J. Anger and the heart: perspectives on cardiac risk, mechanisms and interventions. Prog Cardiovasc Dis. 2013; 55: 538547.

[56] Caska CM, Hendrickson BE, Wong MH, et al. Anger expression and sleep quality in patients with coronary heart disease: findings from the Heart and Soul Study. Psychosom Med. 2009; 71: 280-285.

[57] Vella EJ, Friedman BH. Hostility and anger in: Cardiovascular reactivity and recovery to mental arithmetic stress. Int J Psychophysiol. 2009; 72: 253-259.

[58] Davidson KW, Mostofsky E. Anger expression and risk of coronary heart disease: evidence from the Nova Scotia Health Survey. Am Heart J. 2010; 159: 199-206.
[59] Haas DC, Chaplin WF, Shimbo D, et al. Hostility is an inde pendent predictor of recurrent coronary heart disease events in men but not women: results from a population based study. Heart 2005; 91: 1609-1610.

[60] Stewart JC, Fitzgerald GJ, Kamarck TW. Hostility now, depression later? Longitudinal associations among emotional risk fac tors for coronary artery disease. Ann Behav Med. 2010; 39: 258-266.

[61] Piepoli MF, Hoes AW, Agewall S, et al. 2016 European Guidelines on cardiovascular disease prevention in clinical practice: the Sixth Joint Task Force of the European Society of Cardiology and Other Societies on Cardiovascular Disease Prevention in Clinical Practice (constituted by representatives of 10 societies and by invited experts). Developed with the special contribution of the European Association for Cardiovascular Prevention \& Rehabilitation (EACPR). Eur Heart J. 2016; 37: 2315-2381.

(Balog Piroska, Budapest, Nagyvárad tér 4. XX. emelet, 1089 e-mail: balog.piroska@mail.semmelweis-univ.hu)

\section{MEGHÍVó}

A Szent János Kórház és Észak-budai Egyesített Kórházak Tudományos Bizottsága

tisztelettel meghivja az érdeklődőket a következő tudományos ülésére,

amelyet az I. Belgyógyászati és Gasztroenterológiai Osztály

és a Magyar Gasztroenterológiai Társaság közösen rendez.

Időpont: 2018. december 6. (csütörtök) 14 óra

Helyszín: Szent János Kórház Auditóriuma - 1125 Budapest, Diós árok 1-3.

Téma: Aktualitások a gasztroenterológiában

Üléselnök: Székely György dr., Kazinczy Rita dr.

\section{Program:}

Horváth Gábor dr:: Hepatitis B: Az eredményes terápia nehézségei

Kovács Márta dr: NSAID okozta atípusos elváltozások észlelése kapszulás endoszkópiával

Darvas Emília dr: Az IBS és az ételintolerancia differenciáldiagnosztikája

Székely György dr.: Coeliakia és a microbiom kóros elváltozásai

Sovány Ildikó: Emésztőszervi endoszkópia Prágában - egy asszisztensi konferencia

tapasztalatai

Minden érdeklődőt szeretettel várunk. 